\title{
Communicational types of propaganda
}

\author{
Ştefan Vlăduţescu \\ University of Craiova, 13 A. I. Cuza Street, 200585, Craiova, Romania \\ E-mail address: vladutescus@yahoo.com
}

\section{ABSTRACT}

On a meta-analytical way, the study inventorizes and organizes configures a communicational-persuasive taxonomy of types of propag a. nis expl relevant contributions of some outstanding communication authority propar nda: Serg Yhak an, Jacques Ellul, Jean Cazeneuve, Garth S. Jowett, Victoria O'Donnell, H, A athala, J.- sproule, J. E. Combs, D. Nimmo, Cristian Florin Popescu, Călin Hentea. Asu v totyp f propaganda are recorded vertical and horizontal propaganda; rational and irrational ganda; $\mathrm{p}$ oganda of competition, propaganda of integration and propaganda of subversi n; ideological, po rical, economy, moral, aesthetical, religious, oral, written, visual, audio-vis al, organizational propaganda. The core propaganda will always find the target group. How relev taxonomy $i$ what is done according to the action on the target group: seductive propaganda, propaga mythic a false propaganda, propaganda fiction.

Keywords: communication; persuasion; propagan

\section{INTRODUCTION}

Propaganda i an ivity to promote and disseminate opinions, ideas, theses, conceptions and ctrines, $\mathrm{s}$ sed by a propagator from the positions of an ideology and with the purpo to ause some rects for forming, changing or reinforcing certain opinions, attitudes on havi ans. Sacques Ellul observes that classical propaganda is a vertical propaganda. I tone by a leader, a personality, an authority acting by influence from the height ir pre the target audience is a crowd placed in a position of inferiority. The me age 9 mes from up, and the receiver is generally passive. This form of persuasive com of complementary type. In contradistinction to this, after 1950, a "horizo propaganda" develops on the scientific base of the theory of K. Lewin of dynamics Groups (Ellul J., 1962, pp. 95-96). The horizontal propaganda of sociological orientation is now opposed to the vertical propaganda of ideological nuance. What is important is that both these types remain forms of the propaganda for integration. The criterion for distinguishing between vertical and horizontal propaganda is the direction of propagation. In fact, as a form of propaganda for integration, vertical propaganda crosses history (Buzărnescu, 1996; Borowski, 2013; Borowski, 2014).

It is practiced by the authorities, individuals, political power, political groups. In contemporary, propaganda's specificity is the Globalisation of sending its message through media-type communications. Horizontal propaganda is characterised by dimming the contrast 
between propagandist and target-group. One may say it is based on the equality of group members. Every individual makes propaganda and is object of propaganda, within a global process of influence, support, promotion and exposure to the actions of others.

\section{TAXONOMIES OF PROPAGANDA}

Serghei Chakotin (2004) is the one establishing the typology: rational propaganda, irrational propaganda. According to him, there is a propaganda based on persuacion and reasoning and another one based on suggestion, on engaging the instinctive pulses $n$ emotional exaltation, fear, enthusiasm, ecstatic delirium. Rational propaganda the privile, of democracy. Instead, irrational or sense-propaganda is the tool of totalita ian nes, suc as communism and Nazism. While rational propaganda would be, we sa today, of ritat ve nature, addressing the thinking and characterising by the use of syl isms, amons crons and positive arguments, irrational propaganda is of emotion addre sing the emotional and individualising by the appeal to sophism and free affirmatio

The information from the messages of rational propag a objecti $l$ comes from the technical cultural spheres, it uses static digits. This nform on is integrated into a concrete system of idea and is processed by the logical outure of th ing. The information in the irrational propagandist messages is seductive $\mathrm{hd}$, additionally, $\mathrm{j}$ is processed within a lateral thinking, weak thinking, confused thinking. he affects ar mobilised to persuade the audience in order to adopt the propagandistic messa vithout c unterarguments. When man is seductive, has charm, charisma, what the- shall say seductive, and thus they shall persuade. When the message is seductive, it arsuade. Concerning seduction, there is an ancient Greek legend where an assassin wo nan mitigating circumstances and in despair for a cause removes her robe and she resignedly shows her naked body before the judges. They exonerate her: in $\mathrm{tb}_{\mathrm{s}} \mathrm{ca}$. seduct $\mathrm{n}$ has the desired effect.

Jean Cazeneuve (Caz ve 1976. pp. 359-365) considered three types of propaganda as absolute no ves omm orary propaganda: of competition, of integration and of subversion. With pe propag of competition, one seeks the social change, mainly the political change $t \mathrm{~d}$ lops as an organise conflict: during election campaigns, around the propaganda of overnan or of the field of action of various ideologies. Propaganda of integration ain, to achieve an greement between habits and laws, between ideology and economical polit o structures. Propaganda of subversion serves a political organisation, which aims th ession power by force. It does not serve a democratic ideology, but an undem ic ono

Vict la O'Do ell and Garth S. Jowett (Apud Popescu C. F., 2002, p. 285) consider that ge the types of propaganda: white propaganda, grey propaganda and black vaganar. White propaganda is characterised by that it has a source which is identifiea whech coherently communicates the information and works at its own credibility it is also called open propaganda, official propaganda. White propaganda is done by institutions or public people, states, governments and bodies. The preferred channel to propagate is the media. This way, official documents are promoted, such as: laws, decrees, speeches, standards of national or international politics, press releases, etc. White propaganda generally aims at propagating values, political, economical, military and social rules and principles. It also aims to counteract the adverse propaganda. In short, white propaganda openly assumes its message, is justly declared its producer and transmits it to be received, with the clear awareness of "we". Grey propaganda, show O'Donnell and Jowett, is that the 
source of which "could be or could not be identified correctly" and the information of which does not have a reliable accuracy. It does not openly declare against an opponent or another propaganda.

This makes the topics dealt with to be easily accepted in various circles of the public opinion, but leaves the source in "the grey mist", not disclosing it. Black propaganda is individualised by that it hides its source of propagation or falsely declares the source, with the purpose to get the enemy or the competitor confused. Black propaganda is done when the producing source wants to be known as uninvolved. Black propaganda is also known as undercover propaganda or hidden, masked propaganda. O'Donnelll and Jowett Apud Popescu C. F., 2002, p. 285) consider that "black propaganda is the Big Lie" mis ty propaganda is the most subversive. Black propaganda affirms a source of fal origin for messages. It addresses the opponent directly and openly attacks its mos por Concrete information is generally used, which lead to poisoning the pub ic opinion, fect.ing and weakening the internal solidarity of the group. Ultimately, it lear to tota onfus, and anarchy (Siminică \& Traistaru, 2013; Traistaru \& Avram, 2014) Car are not avoided. Black propaganda generates and disseminate false int ation, modifies, distorts the reality, deforms the truth.

C. F. Popescu believes that "disinformation is (Popescu C. F., 2002, p. 285). The message of black popacanda hid holind the innocence of a non-partisan opinion and issued in good faith. s camouflaged a, information, but one that selects the facts, inserts factoids, changes the ibility scale of certain events in favour for others.

A specific type of propaganda is matapropaga counterpropaganda. Metapropaganda consis helling the information originated from the opponent as propaganda, which automaticall le ascrediting it as information (Arsith \& Draganescu, 2011).

In the scope of propaga aa, come across another three types that are worth mentioning: symbolic propa ${ }^{a}, \mathrm{t}$. tic prop aganda and strategic propaganda. Symbolic propaganda uses allegoric tap conuctions, images and sensitive (not seldom even fictive) representations is based affects, passions, resentments, addressing the obscure layers of the subcop cio Tactic pry paganda is characterised by that it is designed on a short-term in ord get ediate effects. Strategic propaganda is planned to act on a short-term and s destined to ty ing or changing values, basic attitudes and conceptions of the target-gr H.-P. Ca distin ishes three "forms of propaganda" (Cathala H.-P., 1991, pp. 5051):

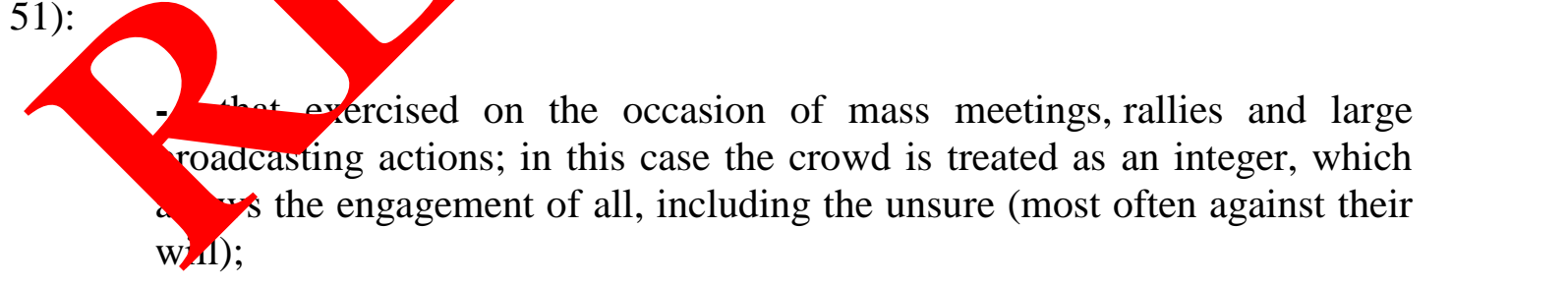

- the "evangelical" one, circulated by priests and missionaries or newsmongers of tendentious rumours; evangelical propaganda currently registers a remarkable success using techniques of mailing, oral or telephonic transmission;

- self-propaganda, that propaganda practiced in limited groups and where everyone is invited to speak completely spontaneous; in reality, observers guiding the debate towards a never omitted topic are present within that 
group; the conclusions are ultimately even firmer, as they appear to be developed in full freedom of thinking; this type of propaganda has been imposed by Mao Zedong.

According to the content, propaganda can be: ideological, political, economical, moral, aesthetical, religious, etc. According to the form: oral, written, visual, audio-visual, organizational. With this typology, propaganda has passed into the $21^{\text {st }}$ Century. He $21^{\text {st }}$ Century did not individualise only regarding the content of propagandistic messages. Evolutions also occurred within the other elements of the operational structure of propaganda. The main character of propaganda is the target-audience. Concernin sthe ta. audience, an essential mutation is generated within the propaganda of the $21^{\text {st }}$ ntury: it 1 . matter here of change from exponents to masses. It is a matter of paronoxic evolutic denying the force of the theory "two-steps-flow". As J.-M. Sproule (Apr a Combs o imr o, 1992, p. 18) showed, "before the $20^{\text {th }}$ Century, persuasive efforts ere d cted th clites consisting of interesting, informed, knowledgeable people. The $p$ ssa as cre ased on the arguments of motivations, facts, based on logic. Howeve the aud no vadays is a mass that replaces the elites. Although they are not passive th asses are always well informed, their interest for politics is sporadic, their direat olitic xperience is low, being trapped in the daily routine. The masses respond to com usions, to reasons, slogans, complex matters, images, ideas, to what is pleasant"

The institution of propaganda is delimited by cee characte istics:

- A specialised silent partner stwicture whi sts of the managerial body and units of organisation, analysis, assessment of the situation of propaganda, as well a ur a designing the actions and propaganda campaigns (mainly propa indistie messages);

- a derived axiology appro riate to goals, objectives and interests of the social group ria rm for designing and im plement the propaganda actions, operations, campaigns; - a set of $\mathrm{m}$ an disseming $\mathrm{g}$ the messages.

In the ac vity of propas a the following are delimited as actors: silent partners, planners and rget- up The silent partners are those who feel the need to ensure a high yield for their i, polit al, economical, military enterprises. They discover propaganda to be a me to ac an objective. Therefore, propaganda is not a goal in itself, but a means amo ig or rs for neving a goal (Otovescu, Frăsie, Motoi \& Otovescu, 2011). The ol ve had is translated by the need for support. In a circumstance or another, silent partnc bserve that the needs, as derivates of the necessity, can be satisfied by getting a support nopaganda, either from the public opinion, or from certain segments of the population/ or from some organisations or bodies. The circumstances where propaganda become a means of achieving certain interests represents what is called a situation of propaganda. The central objective of propaganda is concretely differentiated within the situation of propaganda: triggering some trends of opinion which would form the basis of subsequent elaboration of some attitudes, which would then underlie behaviours (Seceleanu, 2009; Cojocaru, Sandu \& Cojocaru, 2011). Silent partners make the situation of propaganda known to some planners who have the role to design and implement propaganda actions, operations or campaigns, so that the desired effects of support and promotion would be 
achieved (Neacşu, 2005; Olimid, 2013). First of all, planners evaluate whether the situation of propaganda is the one which the silent partners made known. No matter whether it is or it is not the presented one, they, as specialists, configures the real situation of propaganda. In relation to this, re-signifies the interests of which achievement must be supported or based on propaganda. It sets forth the goals and objectives of the action of propaganda, of which the imperative to induce a trend of opinion favourable to supporting and promoting a certain major interest must not be missing. It also designs the propagandistic message and ways of dissemination (Bunea, Cojocaru \& Cojocaru, 2010; Narita, 2013; Hintea, 2013; Oprea, 2013).

Concerning the messages, they carefully give attention to their central topics and-ideas, on coherence, cohesion and their thematic unity. They decide on the speeche wher messages are to be integrated to, as literary genre or discursive form. The acide on channels of dissemination and ways of diffusion: symposium, rallies, medi pos leafle Internet outputs, etc. They order in relation to the area of disseminating the speeches ge and to the financial-logistic means to support the propaganda ope tion campa s. In relation to these, they choose the dissemination operators, set forth the ency of epeating the messages, taking into account the fact that seduction is esper ally gene d by, epetition.

A feed-type device is integrated into the project of th a of prop anda: a set of criteria to discount the effects, to anticipate the effects (fRe forwa and one to correctively adjust the action according to the effects produced, rel woun the goa forth and reactions obtained (feedback). On the other hand, the white, grey or black feg.ure of propaganda is generically given: the source is or is not made $\mathrm{kn}$ vn. The en re project of the action of propaganda has "a single" actor in the centre: the ta t-group. 11 depends on this actor, on knowing this actor. The effects discounted and reaction as sides of the feed device, are fully subordinated to knowing the tar wailure or success of the propaganda action, operation or campaign is fully condit ne sying the target-group. It is not the silent partner's needs to ensure the auccess the propaganda. The discounted effects are presided by the identification the eeds, de ires, aspirations and interests of the targetaudience, by finding the wa car falise the $m$, by selecting the operators and relays to intermediate the message, ac ar wo larget-audience.

Propaganda uses 11 ways informational processing. It acts seductively and mythically on feelin , id will, con cious and latent needs. The target is followed both in the public space ant int space. Propaganda leaves no room for intimacy. The propagandistic aproach sugge a global explanation of the world and engages in providing immediate $r$ ons $o$ cquiescence to the target. In this direction, propaganda is continuous and fierce, it ta ame, be $\mathrm{g}$ "total", as J. Ellul says.

der alfil its purposes and achieve its goals, propaganda is aimed at sub dina $g$ the slic opinion, which is why pressures shall be made in order to sab ina meda to it. Even when it fails, propaganda cannot do without the media. No propas a planner designs their project without taking into account a media component. On this idea, Hentea shows that one cannot "design any military operation without taking into accou 1 t the media component" (Hentea C., 2000, p. 16). Besides these operations, language techniques and cogitative techniques are also present in the portfolio of the propaganda tools. In fact, the propagandistic activities aim to achieve the programmed effects on the opinions, attitudes and behaviour of a target-group, through cogitative-language means. At language level, propaganda deliberately and systematically draws a rhetoric of the transmitted word, into the circuit of influence (Lesutan, 2007; Popa, 2010; Popa, 2011). 


\section{CONCLUSION}

The propaganda actions and campaigns start from the minimal idea that the first effect shall be creating a public opinion by crystallising some latent opinion, by rallying others, conforming the individual dispersed opinions. Concerning the latent opinions, propaganda seductively and mythically stimulates them in the direction of interest, bringing them on a premeditated convergent course. It thus determines the formation of an active trend of public opinion, guided on the coordinates which exist in the propaganda plan. The means and forces make up the propagandistic device. The basis of the activity of propaganda is the Inform. about the target of the propaganda, particularly consisting in knowledge about aspiratio desires, fears and needs of the target-group. The aspirations and fears of th targ nass for the goal which the most important operation of propaganda moves toy ards; sedu $n$. Tne intellectual aspirations shall be attacked by capitalising the myth. Th lie an fiction $O$ not miss from the actions of propaganda.

\section{ACKNOWLEDGMENT}

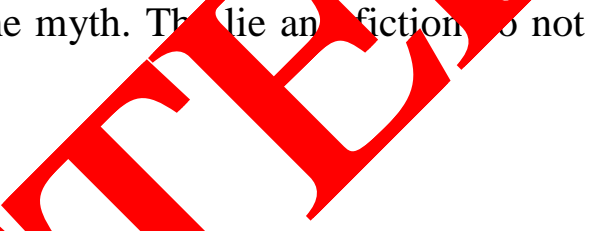
the University of Craiova.

\section{References}

[1] S. Ceakotin (2004). Violul mulţimilor pri pro suo la politică. Bucureşti: Editura Antet.

[2] Andrzej Borowski, Internation tters of Social and Humanistic Sciences 14 (2014) $7-17$.

[3] Jason L. Powell, Intery ocial and Humanistic Sciences 16(2) (2014) 177-183.

[4] Stefan Cojocary Con in Braga a, Transylvanian Review of Administrative sciences 35E (2012)

[5] Ş. Buzăry sscu (1 96). Socidlogia opiniei publice. Bucureşti : Editura Didactică şi Pedagogi

[6] Gonth $r$.

[7] 2009). Analiza opiniei publice în spaţiul public modern. Editura Fundaţiei Ano. Saguna.

[8] Daniela Cojocaru, Antonio Sandu, Stefan Cojocaru, Journal for the Study of Religions and Ideologies 28 (2011) 65-83.

[9] Silviu Neacşu (2005). Sistemul informaţional statistic în învăţământul românesc după 1990. Ed. Fundaţiei Univ. pentru Toţi.

[10] Mădălina Cerban, Analele Universităţii din Craiova. Seria Ştiinţe Filologice. Lingvistică (1-2) (2009) 272-278. 
[11] M. Colhon (2013). Automatic Lexical Alignment between Syntactically Weak Related Languages. Application for English and Romanian. In Computational Collective Intelligence. Technologies and Applications (pp. 266-275). Springer Berlin Heidelberg.

[12] Andrzej Borowski, International Letters of Social and Humanistic Sciences 14 (2014) $33-41$.

[13] L. Oprea (2013). An analytic review of the doctor-patient relationship (part II). Revista Romana de Bioetica.

[14] Doina Mihaela Popa (2010). Comunicarea crizei vs criza comunicarii. St tegii de comunicare a crizei. Anuarul Universităţii" Petre Andrei” Iaşi-Fascicula L t Ştiinţe Economice, Ştiinţe Politice.

[15] Marian Siminică, Aurelia Traistaru, International Journal of Ed 1(12) 2013.

[16] A. Traistaru, M. Avram, International Letters of Social

(2014) 79-88.
[17] Andrzej Borowski, International Letters of Socia cana Humanis, Mences 4 (2013)
70-74. 70-74.

[18] M. Nowicka-Skowron, S. M. Radu (2014). Th formation ind company's innovativecreative activity under the current conditions of marke economy. Communication Neutrosophic Routes. [19] J.-E. Combs, D. Nimmo (1992). The Ne Pr Pu. The Dictatorship of Palaver in
Contemporary Politics. New-York: Lon an.

[20] A. Borowski, Internation Lette of Soci and Humanistic Sciences 11 (2014) 1-168

[21] H.-P. Cathala (1991)

[22] J. Ellul (1962). P gandes. F Armand Colin.

[23] Doina Mihaela opa (1). Patblogia comunicarii, de la semn la simptom. Anuarul Universită, 1 etre Andı Jş̧i-Fascicula Drept, Ştiinţe Economice, Ştiinţe Politice.

[24] Ştefan iocar Papiela Cojocaru (2008). Managementul de caz în protecţia copilului: evaluare. viciilor i practicilor din România. Polirom.

[25] onv arita (2). Public structures. Analele Universităţii Spiru Haret. Seria Jurn: 1 sm.

[26] rez] Borowski, International Letters of Social and Humanistic Sciences 2 (2014) 110

[27] Sanda Antonio (2009). Tehnici afirmativ-apreciative. O sociopedagogie a succesului. Editura Lumen.

[28] G. S. Jowett, V. O'Donnell (Eds.). (2011). Propaganda \& persuasion. Sage.

[29] C. Hentea (2000). 150 de ani de război mediatic. Bucureşti: Editura Nemira.

[30] Stefan Cojocaru, Revista de Cercetare şi Intervenţie socială 20 (2008) 42-48.

[31] Ioan Lesutan (2007). Forme comunicaţionale ale influenţei sociale. Societate si politica. 
[32] Luminiţa Roşca (2004). Producţia textului jurnalistic. Editura Polirom, Iaşi.

[33] Mădălina Cerban (2010). Syntactic relations versus semantic roles within relational framework. Analele Universităţii din Craiova. Seria Ştiinţe Filologice. Lingvistică.

[34] Ştefan Vlăduţescu (2014). Didactic Communication as Tool in European Integration. Communications in Applied Sciences.

[35] Ştefan Viorel Ghenea (2008). Relativism versus Scientific Rationality. Analele Universităţii de Vest din Timişoara.

[36] Cristian Florin Popescu (2002). Dicționar explicativ de jurnalism, relații publicitate. Tritonic.

[37] Alexandra Iorgulescu (2014). Neutrosophic Inflexions in Seneca's Tr Communication Neutrosophic Routes.

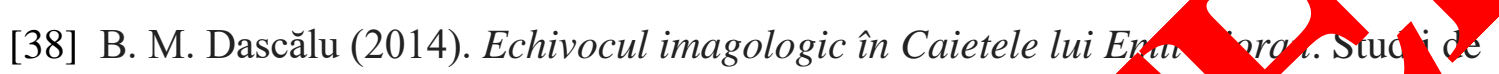
Ştiinţă şi Cultură.

[39] Daniela Gîfu (2014). Humor in the Religious Discours Neutrosophy. Communication Neutrosophic Routes

[40] Cătălina Maria Georgescu (2009). Migraţia forţ de muncă şi sed itatea statelor în spatial european în "Actele Simpozionului Inte haţional Politica Ce vecinătate şi noul spirit european".

[41] Andrezj Borowski, International Letters of Socia 69-74.

[42] O. Bunea, D. Cojocaru, S. Cojocaru (20 D) fam strengthening program. Evaluation report. Social Research Rep

[43] Aurelia Traistaru (2013) onsol lation of he green marketing profile in current austerity period. Joky

[44] Calin Emilian Hir (2013). P icadministration Schools in Romania: Strategic Choices for th utu Revista d. Cercetare şi Intervenţie Socială.

[45] Janusz Gro sara, Michal an, Sebastian Kot, International Journal of Education and Researg 2(2) 014).

[46] Janusz G a, Vlad hir Modrak, Ioan Constantin Dima, International Letters of 5 and ani tic Sciences 15 (2014) 148-156.

[4 Stefa Cojocar, Journal for the Study of Religions and Ideologies 5(13) (2010) 32-38.

[48] Lesutan (2008). Abordarea critică a comunicării - o abordare socială a com is̆rii. Societate si politica.

[49] Anca armena Olimid (2013). Political Change and Democracy Building in Eastern Europe. Rethinking the Theoretical Approaches of Transition. Revista de Stiinte Politice.

[50] Paula Bajdor, Iwona Grabara, Journal of Studies in Social Sciences 7(2) (2014).

[51] Felicia Cornelia Macarie, Călin Hinţea, Cristina Mora, Transylvanian Review of Administrative Sciences (32 E) (2011) 146-156.

[52] Stefan Cojocaru, Journal for the Study of Religions and Ideologies 4(10) (2010) 36-48. 
[53] Ioan Horga, Alina Mogoş (2014). Interests and priorities of EU at Its Southern frontier. Studia Universitatis Babes-Bolyai, Europaea.

[54] Jason L. Powell, International Letters of Social and Humanistic Sciences 7 (2014) 22-30.

[55] Mădălina Strechie (2014). Communication as the Main Source of Neutrality in Ancient Rome. Communication Neutrosophic Routes.

[56] A. Gorun, D. R. Mateiu, H. T. Gorun (2003). Elemente de Administraţie P Jurisprudenţă şi Drept administrativ. Cluj-Napoca.

[57] Goran Rajović, Jelisavka Bulatović, International Letters of Social ar Hum istic Sciences 15(2) (2014) 125-137.

[58] Florica Iuhaş (2012). Mass Media Anthropology: a Post-mode a Id Résê ren. Advanced Research in Scientific Areas. [59] M. Arsith, O. Draganescu (2011). Communication and to izational Mure. EIRP
Proceedings. [60] A. Otovescu, M. A. Frăsie, G. Motoi, D. Otoves u (2011) Criza \y Mială. Editura Pro
Universitaria, Bucureşti.

[61] Stefan Cojocaru (2010). Evaluarea programeld le asistent sociala. Iaşi: Polirom

[62] Moraru Mihai (1997). De nuptiis Mer ii et Phitonger. Editura Fundației Culturale Române.

[63] Jacek Tittenbrun, International Letters of ocial and Humanistic Sciences 9 (2014) 26-48.

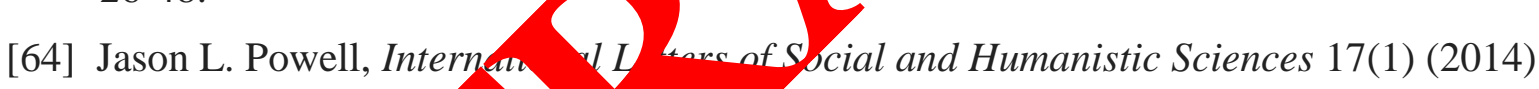
$1-60$.

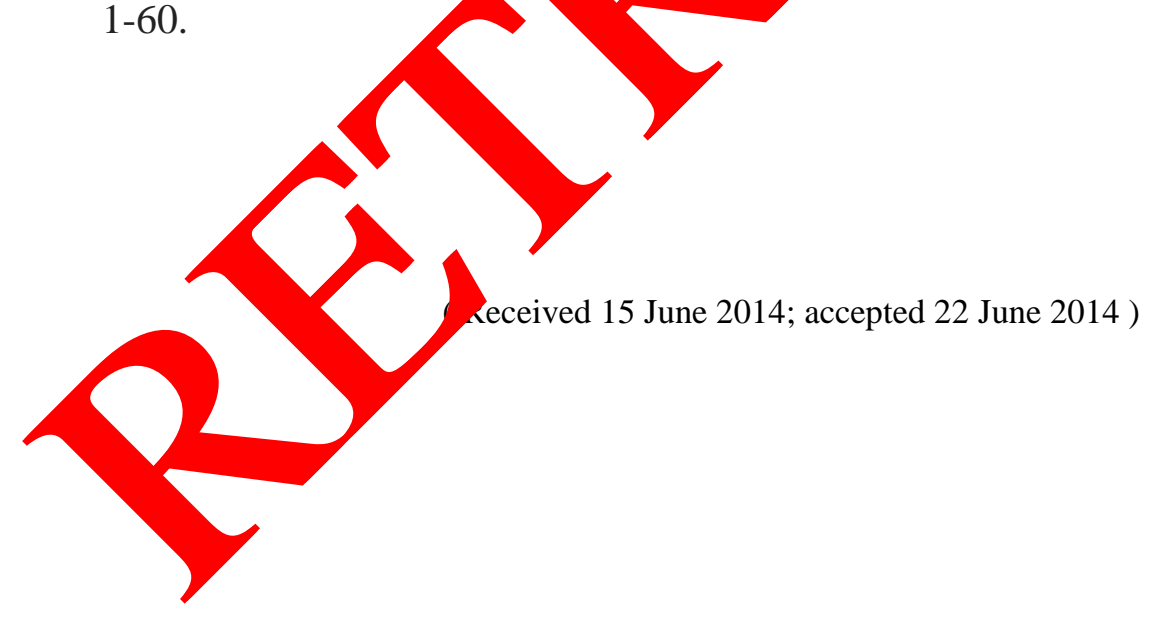

